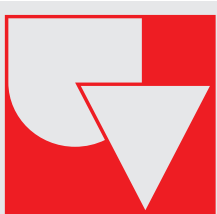

Universidad del Valle

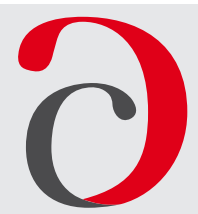

Cuadernos de Administración
Journal of Management

Print ISSN: 0120-4645 / E-ISSN: 2256-5078 / Short name: cuad.adm.

Pages: 31-44 / Vol: 35 / Issue: 65 / Sep. - Dec. 2019

Faculty of Administration Sciences / Universidad del Valle /

Cali - Colombia

\title{
Institutional management: The entrepreneurial intention of the farmers of Aguascalientes
}

\author{
Dirección institucional: La intención emprendedora de los agricultores de Aguascalientes
}

Neftali Parga-Montoya ${ }^{1}$

Research Professor, Department of Agribusiness, Center for Business Sciences, Universidad Autónoma de Aguascalientes, Aguascalientes, Mexico

ORCID ID: https://orcid.org/0000-0003-4832-4103. e-mail: neftali.parga@edu.uaa.mx

Javier Eduardo Vega-Martínez²

Research Professor, Center for Business Sciences, Universidad Autónoma de Aguascalientes, Aguascalientes, Mexico ORCID ID: https://orcid.org/0000-0001-9599-9387. e-mail: javier.vega@edu.uaa.mx

\section{Carlos Eduardo Romo-Bacco ${ }^{3}$}

Research Professor, Department of Agribusiness, Center for Business Sciences, Universidad Autónoma de Aguascalientes, Aguascalientes, Mexico

ORCID ID: https://orcid.org/0000-0002-4410-7470. e-mail: ceromo@correo.uaa.mx

Article of Scientific and Technological Research, PUBLINDEX-COLCIENCIAS classification

Submitted: 16/04/2019 Reviewed: $17 / 07 / 2019$ Accepted: 09/08/2019

Core topic: Administration and Organizations JEL classification: M13, 013, 043

\section{Abstract}

DOI: https://doi.org/10.25100/cdea.v35i65.7774

The study of the institutional context is a relevant topic to measure the factors that affect the intentions of creating a firm. Based on the literature of institutional theory and the theory of planned behavior, chile producers in Mexico are analyzed. The study aims to analyze the influence of regulative, normative and cognitive burdens on the entrepreneurial intention of farmers. An empirical study was carried out with 94 producers located in the state of Aguascalientes. The hypotheses raised were contrasted from multivariate linear regressions. Important results were obtained from the influence of the normative and cognitive burdens on the intentions of entrepreneurship on the part of the producers working as a formal entity. Similarly, this work has crucial contributions to the literature related to academic training and its implications for entrepreneurial intentions, specifically being a variable that favors the penetration of institutional burdens into entrepreneurship.

Keywords: Institutional theory, Entrepreneurial intention, Small-scale farmers.

\footnotetext{
1 Industrial Engineer, Instituto Tecnológico de Aguascalientes Doctor of Administrative Sciences, Universidad Autónoma de Aguascalientes, Mexico.

2 Agroindustrial Engineer, Doctor of Administrative Sciences, Universidad Autónoma de Aguascalientes, Mexico.

3 Agroindustrial Engineer, Doctor in Agricultural, Universidad Autónoma de Aguascalientes.
} 


\section{Resumen}

El estudio del contexto institucional es un tópico relevante para medir aquellos factores que afectan las intenciones de crear una empresa. Teniendo como base la literatura de la teoría institucional se analiza a los productores de chile en México. El estudio tiene como objetivo analizar la influencia de las cargas regulatorias, normativas y cognitivas sobre la intención emprendedora de los agricultores. Se realizó un estudio empírico con 94 productores localizados en el estado de Aguascalientes. Las hipótesis planteadas se contrastaron a partir de regresiones lineales multivariantes. Se obtuvieron importantes resultados de la influencia de las cargas normativas y cognitivas sobre las intenciones de querer emprender por parte de los productores desempeñándose como una entidad formal. De igual forma, este trabajo tiene contribuciones a la literatura relacionada a la formación académica y sus implicaciones en las intenciones emprendedoras, específicamente siendo una variable que favorece la penetración de las cargas institucionales en el emprendimiento.

Palabras clave: Teoría institucional, Intención emprendedora, Productores de pequeña escala.

\section{Introduction}

The literature related to the institutional context has argued that legal conditions, government support provided to farmers (Leite Ferreira, dos Santos Wanzeler, Oliveira, and Oliveira, 2014; Queiroz, Vasconcelos, and Goldszmidt, 2007; Schermer et al., 2016; Slade Shantz, Kistruck, and Zietsma, 2018), generate certainty for crop management (Mugwagwa, Bijman, and Trienekens, 2019; Vasconcelos Pereira Leite, Araújo de Morares, and Santos Salazar, 2016). Under this situation, institutions are triggers for the field development and its markets (Barreto Bernal, 2011). The presence of reliable and inconsistent institutions, where a social source of reference is generated for individuals causes both insecurity and precariousness for the field development (González, Hernández, and Velázquez, 2013).

The context of agriculture in Mexico has become an increasingly important line of business, in six years the growth it has had was $17.6 \%$, likewise, exports had a growth of $42.9 \%$, with a large participation in the agrifood markets as the largest exporter -e.g., avocado, beer, tomato, tequila- (Servicio de Información Agroalimentaria y Pesquera, 2018). However, these results have not been significant for national GDP - only 3.6\% of GDP comes from agriculture (Central Intelligence Agency, 2018)-. Similarly, of the country's economically active population, only $13.3 \%$ work in agricultural activities, mainly composed of producers with basic schooling $(27 \%)$ or without schooling (27\%), having incomes below the minimum wage (54\%) (Servicio de Información Agroalimentaria y Pesquera, 2018).

For this reason, the objective of this research is to analyze the influence of regulatory, normative and cognitive burdens on the entrepreneurial intention of chile producers in the state of Aguascalientes. Thus, examining the conditions in which the institutional framework that governs the Mexican agricultural environment is necessary to assess the quality of the institutional arrangements that rule agribusiness. Hence, allowing the creation, maintenance and change of the composition of institutions that facilitate the interaction of the actors to develop entrepreneurial skills and, so, taking advantage of business opportunities (Da Silva Leonel Junior and Cunha, 2013). Institutional patterns do not converge on the real problems of farmers, consequently, reducing the economic and social bridges that govern farmers' behaviors must be addressed. The intention that these have to develop individual competences to act appropriately in a situation of exploitation of business opportunities (Shapero and Sokol, 1982), would have effects in the way of anticipating obstacles and commercial barriers, in order to allow them to consolidate the investments made (Rizki Novanda, Budi Priyatna, and Budi Priyatna, 2017).

\section{Theoretical framework}

\subsection{Institutional context}

The economic and sociological nature of the institutional perspective explains the complexity of the interrelations present in the economic field by introducing a social reference framework to the model (Granovetter, 1992; Smelser, 2018); where the production, distribution, exchange and consumption of goods and services are derivations of those interactions of groups or 
individuals interested in concluding formal or informal agreements with other economic actors (Granovetter, 1985, 1990; Smelser and Swedberg, 2005). From the beginning of this approach, the assumption of the behavior of individuals in a society is connoted by limited rationality that is directed through social symbolisms such as beliefs, conceptions, norms, rules or laws (Guillén, 1992; North, 1990; Powell and DiMaggio, 1991; Scott, 1995).

The proper functioning of institutional burdens reduces transaction costs and supports individual behavior in favor of society (Roberts and Greenwood, 1997; Williamson, 1975, 1979, 1987, 1989), using interaction as the main basis for achieving both particular and common objectives. Authors like Powell and DiMaggio (1991) have pointed out that the sociological approach contributes to the theoretical discourse of the institutions the interpretation of the mechanisms that regulate the way in which the formal elements are combined with the informal order of the economic entities (Grossman and Helpman 1994), which facilitate, encourage, and govern the actions taken by each one from a perspective of economic benefit (Nee, 2005). The institutional context imposes restrictions so that individuals are governed collectively, hoping to have congruence between group interests with individual goals (Vargas and Restrepo, 2019), the institutional, formal and informal framework, represent the rules of the game where the interactions that shape economic behavior are established. of individuals (North, 1990).

For the scientific literature related to institutional burdens, agribusinesses are an interesting sector, especially agriculture, because they have a significant role in the economic development of a region to combat poverty. Case studies have indicated that the lack of institutional analysis in the creation of legislative mechanisms to support farmers has led to the change of traditional markets to differentiate markets has been due to the inadequate implementation of the operating rules, resulting in a poor governance that legitimizes the generation (Natawidjaja et al., 2008). Dubé, Webb, Arora, and Pingali (2014), in their study, deploy the effort of society to create convergence between agriculture and wealth, which require an institutional framework that positions the public assets of the private and establishes the responsibilities between the state and the market, so that the correct judgment prevails between what the rule of law represents. The analysis of the institutional configuration in agribusiness has been reduced regularly to the present asymmetry, which reduces access to information for some and provides opportunities for others (Mendes, de Carvalho Figueiredo, and Michels, 2008).

In this sense, Mexico has developed two institutional scenarios: on the one hand, there have been important changes in the use of business opportunities within the framework of ideal conditions for the generation of companies that extend to both national and international markets (Grupo Bimbo, Grupo Altex, Grupo Gruma, etc.); however, on the other hand, the links of the chain that are dedicated to the productive issue do not have the resources, strategies and legal mechanisms that allow them to have the conditions for business integration (González et al., 2013). The incompatibility of institutional approaches involved in the support of the productive sector causes the application of resources to be inconsistent and odd to the objectives and functions of those who promote the development of producers (FAO and IICA, 2013).

The institutional environment perceived from different levels - regulatory, normative and cognitive - defines the complexity to which a particular actor is immersed (Scott, 1995), in this case, the farmers. The regulatory aspect distinguishes the commonly obligatory elements that limit or boost the behavior of producers towards following a formal direction to protect productive activities in a legal context (Henisz and Levitt, 2011), generally guide those involved towards increasing wealth and strengthening the local, state or national economy. The normative burden is composed of the elements that reflect the position of society towards that particular actor (Ntayi, Mutebi, Kamanyi, and Byangwa, 2013), it is the social image that others have about the profession of being a farmer, which gives confidence to those who practice the profession ensuring motivation for perform better as a reflection of the acceptance of activity before society. Cognitive elements provide meaning to the 
knowledge acquired throughout the growth of an individual guided by society (Ali, 2015), that is, society provides valuable information and learning so that farmers know how to properly run their business.

From this vision, for Schermer et al. (2016), the regulatory environment is what is allowed to be done, the normative is what is right for society and the cognitive is what is thought of farmers. These aspects as a whole create an inappropriate perception of the profession, affecting the involvement of individuals by a notion of low legal protection, little social acceptance and little knowledge in the area. At this point, Rizki Novanda et al. (2017) point out that the rural areas where it is predominant that activities related to agriculture are carried out are characterized by low economic growth, low productivity and poorly paid employment, causing new generations not to be involved in the sector migrating to the cities integrating to other sectors. A country recognized worldwide for its agricultural sector requires the right policies to motivate and guide society towards the development of the field as a viable option for the evolution of the actors involved.

\subsection{Entrepreneurial intention}

The literature of entrepreneurial intention has distinguished itself by highlighting the behavior of the individual position from the treatment given to the entrepreneurial willingness. The interests of countries to solve the problems of unemployment and economic slowdown in the seventies, contributed to the conceptualization of entrepreneurial intention (Davidsson, 1995). It emerged as the organizational intent to visualize the purposes, goals, habits and behaviors that exist within a company, as symbolic behavior of the cognitive process of its orientation to accept organizational challenges (Katz and Gartner, 1988). The classic economic models have directed their speech towards market systems that treat companies as rational entities that enter and leave the competitive game, exchanging and achieving clear objectives that benefit their exercises, however, the problems present inaccuracies that are known and unknown by who makes the risk decisions, the complex scheme requires personal commitment manifestly as a symbol of direction towards the creation of business opportunities (Reynolds and Miller, 1992).

Krueger and Carsrud (1993) argued that the entrepreneurial intention is a planned cognitive behavior and not a set of beliefs, personality and demographic characteristics, which can be predicted by channels of perceptions, beliefs and exogenous factors that promote the intention to act to the action itself. Intentions serve as an approach to predict behavior reflected in attitudes and intentions acquired through individual and situational perceptions, therefore, the set of attitudes are the result of having developed entrepreneurial behavior (Krueger and Brazeal, 1994). The nature of intentionality is directed towards a specific goal, operating through the individual's attention with effort, persistence and perseverance (Bird, 1988).

Which would be consistent with their attitudes, treatment and actions, as dispositions that infer previously planned behavioral manifestations to make decisions, such as entrepreneuring (Ajzen, 1987). The intention serves as a prediction of entrepreneurship because it encourages the individual towards the performance of a specific action (Ajzen, 1991), because the individual has already perceived, analyzed and conceptualized the context, the opportunity, the resources and the execution process (Ajzen, 1991, 2002). The literature related to entrepreneurial intent is interested in the cognitive perspective that increases the possibilities of developing complex mental processes of storage, transformation and use of information (Ajzen, Czasch, and Flood, 2009; Baron, 2004), to carry out riskprone activities, make judgments to identify the potential of business situations and make decisions according to their knowledge about the opportunities detected (Baron, 1998). In this sense, the mental frameworks concern resources, relationships and assets necessary to undertake, as well as the commitment to support its business idea and the capabilities available to carry it out (Barona and Ward, 2004).

The entrepreneurial process requires exploiting resources available to the farmer to create value through innovation and proper management. The entrepreneurial 
intention is a predisposition to risk to take advantage of the opportunities to undertake (Omidi Najafabadi, Zamani, and Mirdamadi, 2016), therefore, when this perception of risk develops in the farmer, his individual behavior is focused on acquiring more experience, greater knowledge and greater skills to make business decisions (Sargani et al., 2018). Being an engine of socioeconomic implications recognized as a way to improve commercial activity, labor supply and economic development (Shapero, 1975; Sher, Adil, Mushtaq, Ali, and Hussain, 2017). From this perspective, the entrepreneurial intention is a topic little studied in agriculture, significant results have been obtained in studies that analyze the aspiration, rationing and propensity to entrepreneurship (Cavicchi, Rinaldi, and Santini, 2015; Da Silva Leonel Junior and Cunha, 2013; Yaseen, Saleem, Zahra, and Israr, 2018; Yaseen, Somogyi, and Bryceson, 2017).

Therefore, the measurement of entrepreneurial intention has been focused on maintaining the parsimony of taking the interest of carrying out the action to actually apply it (Liñán and Chen, 2009); in this sense, the need to conceptualize the term has inclined literature to validate different measuring instruments that are related to the construct (Covin and Slevin, 1991; Liñán and Chen, 2009; Liñán, Rodríguez-Cohard, and Rueda-Cantuche, 2011; Lumpkin and Dess, 1996; Miller, Kets de Vries, and Toulouse, 1982); however, from the individual notion, the approach of authors like Thompson (2009), accurately deduces the implications of psychometric variables that reduce the respondent's wishes of the social burden and show a more neat measurement of the interest of measuring their intentions.

The purpose of this study is to analyze the effect of institutional burdens on the intention of entrepreneurship of chile producers in the state of Aguascalientes. To contribute to the theoretical and practical discussion of the implications of the institutional structure on the capacity to take advantage of business opportunities in the agriculture sector, from the point of perceived legal protection, the attitudes and skills of the producers developed by their social environment:

$\mathrm{H}_{1}$ : There is influence of the regulatory burden on the entrepreneurial intention of the chile producers in the state of Aguascalientes.

$\mathrm{H}_{2}$ : There is influence of the normative burden on the entrepreneurial intention of the chile producers in the state of Aguascalientes.

$\mathrm{H}_{3}$ : There is influence of the cognitive burden on the entrepreneurial intention of the chile producers in the state of Aguascalientes.

$\mathrm{H}_{4}$ : There is influence of institutional burdens on the entrepreneurial intention of the chile producers in the state of Aguascalientes.

\section{Methodology}

The multiple linear regression statistical technique was used to measure the influence of independent variables on the dependent. The target population were the chile producers of the State of Aguascalientes, because there is no government information available with the location of the entity's farmers, the State Committee for the Chile Product of Aguascalientes (Comité Estatal del Producto Chile de Aguascalientes, CEPROCH) was contacted to request support in the location of the farmers who cultivated different types of chile in the region during 2018. The information collection period was from October to December 2018, to update the list of farmers in the state and thus raise state census information of agricultural producers. Relevant information was obtained to identify those municipalities in the state that have the largest number of hectares of the product cultivated. Cosío and Rincón de Romos unlike Tepezalá and Asientos are the municipalities with the least amount of cultivated territory; while, the municipalities of San José de Gracia, Calvillo and El Llano had no productive activity in 2018 (Figure 1).

(More than 150 hectares / Between 50 to 150 hectares / Between 25 to 50 hectares / Less tan 25 hectares).

As important data to indicate the distribution of the 819 hectares cultivated: 1) $30 \%$ corresponds to fresh jalapeño chile; 2) the territory of cultivation of dried chile barely represents $21 \%$-i.e. the cultivation of processed product-, although it is necessary to consider that most of the producers do 
Figure 1. Cultivated territory in Aguascalientes

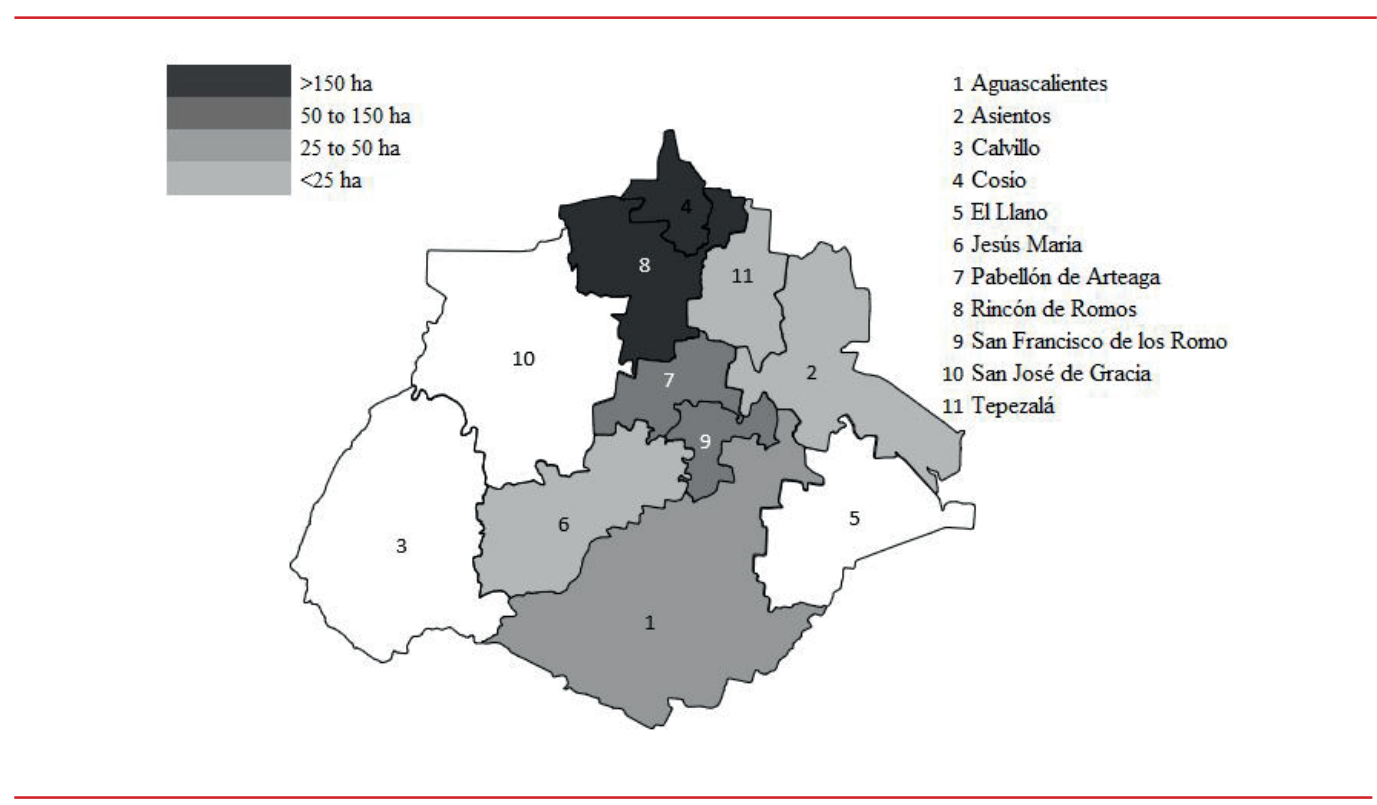

Source: Authors' own elaboration.

not carry out the drying process, taking their fresh product to the link that will be responsible for making the transformation - jalapeño, ancho and pasilla-, missing the opportunity to give it added value to their product; and 3) for the producers, chile is a secondary crop, since they give priority to products such as corn, broccoli and lettuce, these being $78 \%$ of the cultivated land, and there are increasingly opportunities to convert crops to strawberries, asparagus, among others. In regards to the producer profile, we have that: 1) all are men; 2) 58\% are between 45 and 64 years old and only $2 \%$ are under 24 years old; and 3) $21 \%$ do not have schooling, on the other hand, $50 \%$ of farmers have basic education, while only $3 \%$ have a postgraduate degree as academic training.

\subsection{Dependent variable}

With reference to the entrepreneurial intention, a variable was constructed from the average of the data obtained from each of the indicators of the Thompson (2009) scale, which consists of 10 indicators on a 5-point Likert scale that measure the conviction of the individuals to start a new company in a conscientious way taking into consideration the financial and management planning that it performs, the search for opportunities and information gathered for decision making. The indicators were adjusted for the proper interpretation of the terminology used by farmers (Table 1).

\subsection{Independent Variable}

In the case of institutional burdens, 14 structured indicators were used on a 5-point likert scale adapted from the construct developed by Kostova (1999), which considers the regulatory dimensions - law enforcement, government support and difficulty for licensing and procedures - normative uncertainty, reputation and confidence in the farmer - and cognitive - business skills and knowledge that society shares with farmers - (Table 2).

\subsection{Control variables}

The control variables added to the study approach are experience and schooling, with the aim of indicating whether these variables have shared effects with the collaboration networks. On the one hand, the experience will provide the model with the possibility of measuring the effects of those who have worked in the sector and, like these, have a greater entrepreneurial intention. On the other hand, schooling is an essential element 
Table 1. Descriptive indicators of the Entrepreneurial Intention

\begin{tabular}{|c|c|c|c|c|c|}
\hline Variable & Indicators & Median & Std. Dev. & Min. & Max. \\
\hline EI1 & $\begin{array}{l}\text { How important is it for you to try to start a company in } \\
\text { the future? }\end{array}$ & 4.396 & 0.9892 & 1.0 & 5.0 \\
\hline EI2 & How important is it for you to plan your future carefully? & 4.515 & 0.8051 & 1.0 & 5.0 \\
\hline EI3 & $\begin{array}{l}\text { How important is it for you to hear about news related to } \\
\text { farm business? }\end{array}$ & 4.567 & 0.6908 & 1.0 & 5.0 \\
\hline EI4 & $\begin{array}{l}\text { How important is it for you to look for opportunities to } \\
\text { create a new farming business? }\end{array}$ & 4.515 & 0.7653 & 1.0 & 5.0 \\
\hline EI5 & $\begin{array}{l}\text { How important is it for you to learn about agricultural } \\
\text { activity management? }\end{array}$ & 4.608 & 0.7297 & 1.0 & 5.0 \\
\hline EI6 & $\begin{array}{l}\text { How important is it for you to save money to start new } \\
\text { crops? }\end{array}$ & 4.515 & 0.8306 & 1.0 & 5.0 \\
\hline EI7 & $\begin{array}{l}\text { How important is it for you to learn about starting a } \\
\text { business? }\end{array}$ & 4.577 & 0.6588 & 1.0 & 5.0 \\
\hline EI8 & $\begin{array}{l}\text { How important is it for you to have plans to start your own } \\
\text { business? }\end{array}$ & 4.619 & 0.6365 & 1.0 & 5.0 \\
\hline EI9 & $\begin{array}{l}\text { How important is it for you to invest your time learning } \\
\text { about how to start a business? }\end{array}$ & 4.443 & 0.8288 & 1.0 & 5.0 \\
\hline EI10 & $\begin{array}{l}\text { How important is it for you to consider bank credits to } \\
\text { invest in your production? }\end{array}$ & 3.969 & 1.4324 & 1.0 & 5.0 \\
\hline
\end{tabular}

\begin{tabular}{|c|c|c|c|c|c|}
\hline Variable & Indicators & Median & Std. Dev. & Min. & Max. \\
\hline AR1 & $\begin{array}{l}\text { How important are the procedures for your activity (well licenses, } \\
\text { water extraction certificates, private and ejidal property, etc.)? }\end{array}$ & 4.670 & 0.5723 & 2.0 & 5.0 \\
\hline AR2 & $\begin{array}{l}\text { How important is the cost of taxes for activity (Proof of Compliance } \\
\text { 32D) for producers? }\end{array}$ & 4.567 & 0.8024 & 1.0 & 5.0 \\
\hline AR3 & $\begin{array}{l}\text { How important is it that laws and taxes are applied equally among } \\
\text { all producers? }\end{array}$ & 4.454 & 0.8663 & 1.0 & 5.0 \\
\hline AR4 & How important is the SAGARPA Single Beneficiary Register System? & 4.485 & 0.7653 & 1.0 & 5.0 \\
\hline AN1 & How important is it for society to be a producer? & 4.448 & 0.9610 & 1.0 & 5.0 \\
\hline AN2 & How important is it for you to be a producer? & 4.771 & 0.4225 & 4.0 & 5.0 \\
\hline AN3 & $\begin{array}{l}\text { How important is it for you that successful producers are treated } \\
\text { with respect? }\end{array}$ & 4.740 & 0.5077 & 2.0 & 5.0 \\
\hline AN4 & $\begin{array}{l}\text { How important are the stories of successful producers in the mass } \\
\text { media (newspaper, magazines, radio, television, Internet, etc.) to } \\
\text { you? }\end{array}$ & 4.588 & 0.6575 & 1.0 & 5.0 \\
\hline AN5 & $\begin{array}{l}\text { How important is it for you that producers are considered competent } \\
\text { people? }\end{array}$ & 4.649 & 0.6621 & 1.0 & 5.0 \\
\hline AC1 & How important is the experience for producers? & 4.856 & 0.3532 & 4.0 & 5.0 \\
\hline $\mathrm{AC} 2$ & How important is to react to good opportunities for producers? & 4.753 & 0.5210 & 2.0 & 5.0 \\
\hline AC3 & $\begin{array}{l}\text { How important is it for the producer to have the ability to obtain the } \\
\text { necessary resources to develop their activity? }\end{array}$ & 4.856 & 0.3532 & 4.0 & 5.0 \\
\hline AC4 & How important is it for a producer to grow their activity? & 4.866 & 0.3424 & 4.0 & 5.0 \\
\hline AC5 & How important is it that a producer knows how to direct their plot? & 4.928 & 0.2601 & 4.0 & 5.0 \\
\hline \multicolumn{6}{|c|}{ Source: Authors' own elaboration. } \\
\hline
\end{tabular}


in the decision making that producers have, so its measurement allows the study to give greater importance to the impact that education has on the aspirations to be undertaken.

\section{Results and discussion}

The descriptive results of the analyzed variables are presented. By indicators, it was observed that the highest average of the entrepreneurial intention were the plans to start a business $(4.62=$ Important $)$ with a standard deviation of .64; while the lowest average was bank financing as mobile to invest in production (3.97 = Not important) with a standard deviation of 1.43 (Table 1). The indicators of institutional burdens were concentrated in the range of 4 to 5 Likert points, however, it was observed that the lowest average and the highest standard deviation was in the same indicator that measures the importance of being a farmer for society (4.45 and .96 points respectively); on the other hand, the highest median also corresponded to the lowest standard deviation in the indicator that measures the knowledge learned about knowing how to manage a plot (4.93 and .26 points respectively) (Table 2).

In relation to the descriptive results (Table 3), it was observed that the average experience was 28 years with a standard deviation of 16.34; while the average schooling was middle school. The regulatory burden had a value of 4.54 (Very important) with the highest deviation of the three institutional burdens (0.59); the normative burden was estimated at a value of 4.64 (Very important) with a standard deviation of 0.42; Finally, the cognitive burden was valued at 4.85 (Very important) with the lowest standard deviation of the three (0.30). On the other hand, the entrepreneurial intention had an average of 4.47 (Very important) and a standard deviation of 0.65. The variance inflation factor, which indicates the absence of multicollinearity problems (Table 3). In the same way, the correlations are presented (Table 3), which shows that the statistically significant positive correlations have a range of -.40 to .43 . It was observed that the correlations of the entrepreneurial intention with the institutional burdens were significant in two cases: normative $(r=.30$; $\left.\mathrm{r}^{2}=.09\right)$ and cognitive $\left(\mathrm{r}=.23 ; \mathrm{r}^{2}=.05\right)$. These correlations reflect the relationships of the variables without being affected by the experience and education of the producers. Previous studies have obtained the same results with respect to the effect of institutional burdens on entrepreneurial aspirations (Ali, 2015; Díaz-Casero, Ferreira, Hernández Mogollón, and Barata Raposo, 2012; Liñán and Chen, 2009; Urban and Kujinga, 2017), which have been consistent with the presented results. An important finding was that normative burdens are more significant, which implies the effect of the environment's trust towards producers in their entrepreneurial aspirations.

Table 4 shows the results obtained from the multiple linear regression analysis calculated with the 94 chile producers. In the first instance, in the calculation of the regulatory burden model together with the experience and schooling variables (A), although the model is significant $\left(r^{2}\right.$ $=.212 ; \mathrm{F}=6.06^{* * *}$ ), only schooling has a positive influence and significant about the entrepreneurial intention ( $\mathrm{B}=.132 * *$; $\mathrm{EE}$ $=.051)$. When adding the normative burden to model (B), the effects of both charges were significant, the regulatory burden was significant at 5\% (B = .102 **; EE = .106) and the regulatory burden was significant at $1 \%$ $(\mathrm{B}=.353 * * * ; \mathrm{EE}=.147)$, likewise, schooling had a significance of $5 \%(\mathrm{~B}=.125 *$; $\mathrm{EE}=$ .049). In the individual model of the normative burden (C), this burden was significant at $1 \%(\mathrm{~B}=.356 * * * ; \mathrm{EE}=.144)$, in addition to significant schooling at $5 \%(\mathrm{~B}=.126 * *$; $\mathrm{EE}$ $=.049$ ). In the case of the model that groups both the normative and the cognitive load (D), the two contemplated loads were significant, while the normative load was significant at $5 \%(\mathrm{~B}=.208 * * * ; \mathrm{EE}=.160)$. Individually (E), the effect of cognitive load was significant at $1 \%(\mathrm{~B}=.371 * * * ; \mathrm{EE}=.204)$, as well as, $5 \%$ schooling $(\mathrm{B}=.116 * * ; \mathrm{EE}=.050)$. In the model where the regulatory and cognitive loads (F) are combined, the cognitive load was significant at $1 \%(\mathrm{~B}=.371 * * * ; \mathrm{EE}$ $=.215)$, while schooling was significant at $5 \%(\mathrm{~B}=.116 * * ; \mathrm{EE}=.051)$. Finally, when evaluating the model of the three institutional burdens (G), an increase in the variation of the statistically significant entrepreneurial intention was identified ( $\mathrm{r} 2=.266 ; \mathrm{F}=5,316$ $* * *)$, with respect to the $\mathrm{B}$ coefficients of the 
Table 3. Statistical Summary and Bivariate Correlations

\begin{tabular}{|c|c|c|c|c|c|c|c|c|c|c|}
\hline & & Median & Std. Dev. & VIF & 1 & 2 & 3 & 4 & 5 & 6 \\
\hline 1 & Experience & 28.35 & 16.34 & 1.36 & 1 & & & & & \\
\hline 2 & Schooling & 2.92 & 1.39 & 1.35 & $-0.40 * * *$ & 1 & & & & \\
\hline 3 & Regulatory Burden & 4.54 & 0.59 & 1.14 & -0.16 & 0.18 & $(0.78)$ & & & \\
\hline 4 & Normative Burden & 4.64 & 0.42 & 1.29 & -0.18 & 0.16 & $.20 * *$ & (.61) & & \\
\hline 5 & Cognitive Burden & 4.85 & 0.30 & 1.37 & -0.02 & 0.20 & $.30 * * *$ & $.43^{* * *}$ & $(.85)$ & \\
\hline 6 & $\begin{array}{l}\text { Entrepreneurial } \\
\text { Intention }\end{array}$ & 4.47 & 0.65 & & $-0.35^{* * *}$ & $.40 * * *$ & 0.12 & $.30 * * *$ & $.23 * *$ & $(.90)$ \\
\hline \multicolumn{11}{|c|}{$\begin{array}{l}\text { Observations }=94 ; \text { Cronbach coefficients are reported in parentheses } \\
{ }^{*} \mathrm{p}<.1 ; * * \mathrm{p}<.05 ; * * * \mathrm{p}<.01\end{array}$} \\
\hline
\end{tabular}

\begin{tabular}{|c|c|c|c|c|c|c|c|}
\hline & A & B & C & D & $\mathbf{E}$ & $\mathbf{F}$ & G \\
\hline \multirow[t]{2}{*}{ Constant } & 4.310 & 2.87 & 2.904 & 2.291 & 2.816 & 2.816 & 2.304 \\
\hline & $(0.554)$ & $(0.808)$ & $(0.744)$ & (1.033) & $(1.007)$ & $(1.023)$ & $(1.047)$ \\
\hline \multicolumn{8}{|l|}{ Control Variables } \\
\hline \multirow[t]{2}{*}{ Regulatory burdens } & 0.056 & 0.102 & & & & 0.000 & -0.011 \\
\hline & $(0.107)$ & $(0.106)$ & & & & $(0.111)$ & (.109) \\
\hline \multirow[t]{2}{*}{ Normative Burdens } & & $0.353^{* * *}$ & $0.356^{* * *}$ & $0.296^{* * *}$ & & & $0.297 * * *$ \\
\hline & & $(0.147)$ & $(.144)$ & $(0.160)$ & & & $(0.161)$ \\
\hline \multirow[t]{2}{*}{ Cognitive Burdens } & & & & 0.192 & $0.371 * * *$ & $0.371 * * *$ & 0.197 \\
\hline & & & & $(.224)$ & $(0.204)$ & $(0.215)$ & $(0.232)$ \\
\hline \multirow[t]{2}{*}{ Experience } & -0.006 & -0.004 & -0.004 & -0.005 & -0.007 & -0.007 & -0.005 \\
\hline & $(0.005)$ & $(0.005)$ & $(.005)$ & $(0.005)$ & $(0.005)$ & $(0.005)$ & $(.005)$ \\
\hline \multirow[t]{2}{*}{ Schooling } & $0.132 * *$ & $0.125^{* *}$ & $0.126^{* *}$ & $0.117^{* *}$ & $0.116^{* *}$ & $0.116 * *$ & $0.118^{* *}$ \\
\hline & $(0.051)$ & $(0.049)$ & $(.049)$ & $(.050)$ & $(0.050)$ & $(0.051)$ & $(.050)$ \\
\hline $\mathrm{R} 2$ & 0.212 & 0.260 & 0.260 & 0.266 & 0.238 & 0.238 & 0.266 \\
\hline R2-Adjusted & 0.177 & 0.218 & 0.227 & 0.225 & 0.204 & 0.195 & 0.216 \\
\hline F & $6.06 * * *$ & $6.254^{* * *}$ & $7.901 * * *$ & $6.449 * * *$ & $7.019 * * *$ & $5.553 * * *$ & $5.316^{* * *}$ \\
\hline Observations & 94 & & & & & & \\
\hline \multicolumn{8}{|c|}{$\begin{array}{l}\text { Dependent Variable: Entrepreneurial Intention. Standard coefficients and errors are reported in parentheses. } \\
{ }^{*} \mathrm{p}<.1 ; * * \mathrm{p}<.05 ; * * * \mathrm{p}<.01\end{array}$} \\
\hline \multicolumn{8}{|c|}{ Source: Authors' own elaboration. } \\
\hline
\end{tabular}

variables of the model, the normative load (B $=.297 * * * ; \mathrm{EE}=.050)$ was significant at $1 \%$, as well as schooling at 5\% $(\mathrm{B}=.118 * * ; \mathrm{EE}=$ $.050)$.

The empirical results obtained demonstrate the importance of institutional burdens in entrepreneurial intent, on the one hand, the normative burden, being significant in models B, C, D and G. This implies that society's confidence in farmers influences the way they aspire to be entrepreneurs. On the other hand, the cognitive load is a variable that is significant when the normative load is not within the model ( $\mathrm{E}$ and $\mathrm{G}$ ), it follows that despite the skills and knowledge that 
can be disseminated socially in a region, they do not contribute to the variation of the entrepreneurial intention, since the normative burden is more important for the explanation of the variable. An important finding was that the regulatory burden has not been significant for the proposed models, which explains that the intervention of the state in the development of the cognitive process of farmers to rationalize entrepreneurship as a need to identify business opportunities is nil, in this sense, a contribution of the study was that the academic training of farmers gives greater tools to assimilate the commitment to undertake.

As it has been mentioned, the perception that farmers have of entrepreneurship starts from an institutional pattern, the elements contemplated in the institutional theory are evaluated from a sociological scheme in which those constructions that are recognized within a society are considered, in the case In the state of Aguascalientes, institutional burdens have limited the entrepreneurial behavior of chile producers from two strategic points; 1) the regulatory burden is a mechanism that should protect and encourage the intentions of developing business by farmers; and 2) in spite of the resources invested in support and support programs dedicated to developing business skills in the productive sector, they have not produced results to form an entrepreneurial intention. As in the Schermer et al. (2016) study, skills are restricted by the regulatory aspect, preventing them from adapting to both social and climatic changes.

Also, it was observed that the cognitive load, which is what prepares individuals to cope with the activity in which they perform, is limited to support a business idea and develop it; furthermore, the acceptance of using this valuable information to implement it in their daily activities is conditioned by the existing trust that does not ensure sufficient motivation to dedicate themselves to their profession. As concluded by Rizki Novanda et al. (2017), the particular beliefs, customs and habits of the sector have made farmers reluctant to perceive or develop attitudes that strengthen their intentions to grow. For this reason, the involvement of new generations in the activities of the field is decreasing, which makes sense, with the little involvement of young people in the surveyed farmer population, reflecting a generation of producers who do not intend to develop a professional career in the agriculture sector.

\section{Conclusion}

The influence of the normative burden was statistically significant in the proposed regression models $\left(\mathrm{H}_{2}\right)$; the cognitive load was only statistically significant when the normative load is not present in equation $\left(\mathrm{H}_{3}\right)$; on the contrary, the regulatory burden was rejected in the statistical models for not contributing to the generation of an entrepreneurial intention $\left(\mathrm{H}_{1}\right)$. Integrating the three loads into the regression model, only the normative load was statistically significant $\left(\mathrm{H}_{4}\right)$. The combination of results by the analyzes carried out is the consequence of the quality of the institutional arrangements in which the farmers operate. Improving the agriculture sector requires new approaches, which escalate in the convergence of its activities and needs. The analysis of the institutional framework offers both political and economic functional responses, in which the role of producers is protected as a spectrum of great relevance in the rural sector, so that solid agricultural structures are generated that strengthen professions aligned with agricultural production which guarantees the transition from being $a$ productive chain to being a value chain.

This study contributes to the institutional perspective, the explanation of the entrepreneurial aspirations by farmers from an institutional environmental conceptualization, which is composed of social perceptions, knowledge and formal rules that represent the main key to take advantage of the opportunities that exist in the market. Corroborating the effect of these environmental conditions allows to establish clear parameters about the scope of public policies and the understanding of entrepreneurial behavior. In this way, the theoretical implications contribute to the development of the sector through the understanding of the factors that represent barriers or impulses for those involved in agricultural production. In the review of the literature associated with farmers, the formal and informal mechanisms to which 
agricultural sector actors are governed regularly are notaligned with their productive practices or with their motivations to start businesses.

In the practical matter, the practical implications of the study are related to the critical perception that farmers have about the entrepreneurial intention and how it is affected by social image conditions rather than by the regulatory or cognitive limitations they have, a scenario that must be considered by those who make policies to potentiate the perceptions of desirability and entrepreneurial feasibility of farmers, having identified that institutional burden with greater relevance to develop entrepreneurial aspirations, which can generate government guidelines that extend the capacities of producers towards strengthening of their social image as specialists in the field sector, in order to promote a direction towards the common interest of field activities for new generations, being critical actors for the exploitation of business opportunities raised in the context of the study. In other words, the region must be triggered by pursuing the empowerment of producers based on the construction of their entrepreneurial intention and involving those responsible for developing the chile production as a value chain. The agricultural sector requires formal configuration under measurable standards of quality, efficiency and market potential because this gives certainty to the actors, allowing entrepreneurial decisions to be made under ideal conditions of economic growth, since the institutional context would provide them with legal protection, a positive perception of their economic activity and the formation of skills necessary to undertake new business ideas or developing specific innovations that impact their performance.

Future lines of study are focused on investigating the association of producers to identify those main actors that share relevant information for both the commercial and training production chain, which would be important to know to force the consolidation of a value chain that has the ability to innovate in the global market. Also as a future line, it is convenient to determine those institutional forces that have had the greatest impact on producers, be it government support, collaboration networks or the legal framework demarcate a fundamental sense in which farmers support themselves to carry out their productive activities. A poorly developed line, but just as important for this sector, is the absorption capacities of farmers, since they allow individuals to receive, manipulate, manage and use valuable information to make decisions according to their resources and capabilities.

\section{Conflict of interest}

The authors declare no conflict of interest.

\section{Source of Financing}

This work was funded by the Government of Mexico, specifically by the Program for Scholar Professional Development of the Ministry of Education, registered in the Agreement 19/12/17.

\section{Acknowledgments}

The authors acknowledge fully the Program for Scholar Professional Development of the Ministry of Education for supporting the development of this investigation in a sector that lacks scientific research.

\section{References}

Ajzen, I. (1987). Attitudes, Traits, and Actions: Dispositional Prediction of Behavior in Personality and Social Psychology. In L. Berkowitz (Ed.), Advances in Experimental Social Psychology (Vol. 20, pp. 1-63). Madison, USA: Academic Press.

Ajzen, I. (1991). The theory of planned behavior. Organizational Behavior and Human Decision Processes, 50(2), 179-211. doi:https://doi. org/10.1016/0749-5978(91)90020-T

Ajzen, I. (2002). Perceived Behavioral Control, Self-Efficacy, Locus of Control, and the Theory of Planned Behavior. Journal of Applied Social Psychology, 32(4), 665-683. doi: 10.1111/j.15591816.2002.tb00236.x

Ajzen, I., Czasch, C., \& Flood, M. G. (2009). From IntentionstoBehavior: Implementation Intention, Commitment, and Conscientiousness1. Journal of Applied Social Psychology, 39(6), 1356-1372. doi: 10.1111/j.1559-1816.2009.00485.x 
Ali, D. (2015). The effects of demographic, cognitive and institutional factors on development of entrepreneurial intention: Toward a sociocognitive model of entrepreneurial career. Journal of International Entrepreneurship, 13, 452-476.

Baron, R., \& Ward, T. (2004). Expandind Entrepreneurial Cognition's Toolbox: Potential Contributions from the Field of Cognitive Science. Entrepreneurship Theory adn Practice, 28(6), 553-573.

Baron, R. A. (1998). Cognitive mechanisms in entrepreneurship: Why and when enterpreneurs think differently than other people. Journal of Business Venturing, 13(4), 275-294. doi: https:// doi.org/10.1016/S0883-9026(97)00031-1

Baron, R. A. (2004). The cognitive perspective: a valuable tool for answering entrepreneurship's basic "why" questions. Journal of Business Venturing, 19(2), 221-239. doi: https://doi. org/10.1016/S0883-9026(03)00008-9

Barreto Bernal, P. C. (2011). Estrategia e intervención estatal en la siderúrgica colombiana: consideraciones desde el institucionalismo. Cuadernos de Administración, 27(46), 115-129. doi: https://doi.org/10.25100/ cdea.v27i46.88

Bird, B. (1988). Implementing Entrepreneurial Ideas: The Case for Intention. The Academy of Management Review, 13(3), 442-453. doi:10.2307/258091

Cavicchi, A., Rinaldi, C., \& Santini, C. (2015). Fostering entrepreneurial education in Agribusiness through experiential learning. Proceedings in Food System Dynamics, 470-476.

Central Intelligence Agency. (2018). The World Factbook. Washington, DC Retrieved from https://www.cia.gov/LIBRARY/publications/ the-world-factbook/geos/mx.html

Covin, J., \& Slevin, D. (1991). A Conceptual Model of Entrepreneurship as Firm Behavior. Entrepreneurship Theory and Practice, 16(1), 7-25.

Da Silva LeonelJunior, R., \& Cunha, C. (2013).Atores, trabalho institucional e a institucionalização da estratégia de diversificação em uma cooperativa agroindustrial. BASE - Revista de Administração e Contabilidade da Unisinos, 10(1), 81-98. doi: 10.4013/base.2013.101.07

Davidsson, P. (Producer). (1995). Determinants of Entrepreneurial Intentions. Retrieved from https://eprints.qut.edu.au/2076

Díaz-Casero, J. C., Ferreira, J. J. M., Hernández
Mogollón, R., \& Barata Raposo, M. L. (2012). Influence of institutional environment on entrepreneurial intention: a comparative study of two countries university students. International Entrepreneurship and Management Journal, 8(1), 55-74. doi: 10.1007/ s11365-009-0134-3

Dubé, L., Webb, P., Arora, N. K., \& Pingali, P. (2014). Agriculture, health, and wealth convergence: Bridging traditional food systems and modern agribusiness solutions. Annals of the New York Academy of Sciences, 1331(1), 1-14. doi: https://nyaspubs.onlinelibrary.wiley.com/doi/ full/10.1111/nyas.12602

FAO, IICA. (2013). Apoyo del sector público para el desarrollo de los agronegocios incluyentes - Análisis del modelo institucional de Chile. Recuperado de http://www.fao.org/3/a-i4076s. pdf

González, O., Hernández, N. M. B., \& Velázquez, J. E. R. (2013). Los agronegocios y su institucionalidad en México en el 2012. DELOS: Desarrollo Local Sostenible, 6(16), 2.

Granovetter, M. (1985). Economic Action and Social Structure: The Problem of Embeddedness. American Journal of Sociology, 91(3), 481-510.

Granovetter, M. (1990). The old and the new economic sociology: A history and an agenda. Utah, USA: Aldine Transaction.

Granovetter, M. (1992). Economic Institutions as Social Constructions: A Framework for Analysis. Acta Sociologica, 35(1), 3-11.

Grossman, G. M., \& Helpman, E. (1994). Protection for Sale. The American Economic Review, 84(4), 833-850.

Guillén, M. F. (1992). Reviewed Work: The New Institutionalism in Organizational Analysis by Walter W. Powell, Paul J. Dimaggio. Reis: Revista Española de Investigaciones Sociológicas(59), 344-346. doi: 10.2307/40183831

Henisz, W., \& Levitt, R. (2011). Regulative, Normative and Cognitive Institutional Supports for Relational Contracting in Infrastructure Projects. Retrieved from https://gpc.stanford. edu/sites/default/files/wp055-1 0.pdf

Kostova, T. (1999). Transnational Transfer of Strategic Organizational Practices: A Contextual Perspective. Academy of Management Review, 24(2), 308-324.

Katz, J., \& Gartner, W. B. (1988). Properties of Emerging Organizations. 13(3), 429-441. doi: 10.5465/amr.1988.4306967 
Krueger, N. F., \& Brazeal, D. V. (1994). Entrepreneurial Potential and Potential Entrepreneurs. 18(3), 91-104. doi:10.1177/104225879401800307

Krueger, N. F., \& Carsrud, A. L. (1993). Entrepreneurial intentions: Applying the theory of planned behaviour. Entrepreneurship \& Regional Development, 5(4), 315-330. doi:10.1080/08985629300000020

Leite Ferreira, L. M., dos Santos Wanzeler, M., Oliveira, R., \& Oliveira, A. (2014). Cost Management in Agribusiness: study profitability scenarios of Integrated System vs. Independent System for a Poultry Producer. Independent Journal of Management \& Production, 5(2), 493510. doi: 10.14807/ijmp.v5i2.160

Liñán, F., \& Chen, Y. W. (2009). Development and Cross-Cultural Application of a Specific Instrument to Measure Entrepreneurial Intentions. Entrepreneurship Theory and Practice, 33(3), 593-617. doi:10.1111/j.1540-6520.2009.00318.x

Liñán, F., Rodríguez-Cohard, J. C., \& RuedaCantuche, J. M. (2011). Factors affecting entrepreneurial intention levels: a role for education. International Entrepreneurship and Management Journal, 7(2), 195-218. doi: 10.1007/ s11365-010-0154-Z

Lumpkin, G. T., \& Dess, G. (1996). Clarifying the Entrepreneurial Orientation Construct and Linking it to Performance. Academy of Management Review, 21(1), 135-172.

Mendes, K., de Carvalho Figueiredo, J., \& Michels, I. L. (2008). A nova economia institucional e sua aplicação no estudo do agronegócio brasileiro. Revista de Economia e Agronegócio, 6(3), 309-342.

Miller, D., Kets de Vries, M., \& Toulouse, J.-M. (1982). Top Executive Locus of Control and Its Relationship to Strategy-Making, Structure, and Environment. Academy of Management Journal, 25(2), 237-253.

Mugwagwa, I., Bijman, J., \& Trienekens, J. (2019). Why do agribusiness firms simultaneously source from different contract farming arrangements? Evidence from the soybean industry in Malawi. International Food and Agribusiness Management Review, 22(1), 79-96. doi: 10.22434/ifamr2018.0079

Natawidjaja, R., Deliana, Y., Rusastra, W., Perdana, T., A Napitupulu, T., Sulistyoningrum, H., \& M Rahayu, Y. (2008). The transparent margin partnership model: Linking mango farmers to dynamic markets. Retrieved from https://www. actahort.org/books/794/794_31.htm
Nee, V. (2005). The new institutionalisms in economics and sociology. The handbook of economic sociology, 2, 49-74.

North, D. (1990). Institutions, Institutional Change and Economic Performance. Cambridge, UK: Cambridge University Press.

Ntayi, J. M., Mutebi, H., Kamanyi, S., \& Byangwa, K. (2013). Institutional framing for entrepreneurship in sub-Saharan Africa: a case of Uganda. World Journal of Entrepreneurship, Management and Sustainable Development, 9(2/3), 133-154. doi: 10.1108/ WJEMSD-01-2013-0016

Omidi Najafabadi, M., Zamani, M., \& Mirdamadi, M. (2016). Designing a model for entrepreneurial intentions of agricultural students. Journal of Education for Business, 91(6), 338-346. doi:10.1 $\underline{080 / 08832323.2016 .1218318}$

Powell, W. W., \& DiMaggio, P. J. (1991). The new institutionalism in organizational analysis. Chicago, USA: University of Chicago Press.

Queiroz, M. A. L. d., Vasconcelos, F. C. d., \& Goldszmidt, R. G. B. (2007). Economic rents and legitimacy: incorporating elements of organizational analysis institutional theory to the field of business strategy. BAR - Brazilian Administration Review, 4, 51-65.

Reynolds, P., \& Miller, B. (1992). New firm gestation: Conception, birth, and implications for research. Journal of Business Venturing, 7(5), 405-417. doi: https://doi.org/10.1016/0883-9026(92)90016-K

Rizki Novanda, R., Budi Priyatna, B., \& Budi Priyatna, W. (2017). Entrepreneurship intention in agricultural sector of young generation in Indonesia. Asia Pacific Journal of Innovation and Entrepreneurship, 11(1), 76-89. doi: 10.1108/ APJIE-04-2017-022

Roberts, P., \& Greenwood, R. (1997). Integrating Transaction cost and Institutional Theories: Toward a Constrained-Efficiency Framework for understanding Organizational Design Adoption. Academy of Management Review, 22(2), 346-373.

Sargani, G. R., Deyi, Z., Magsi, H., Noonari, S., Joyo, A., Muhammad, S., \& Kazmi, M. (2018). An Empirical Study of Attitude Towards Entrepreneurial Intention among Pakistan and China Agricultural Graduates in Agribusiness. The International Journal of Business Management and Technology, 2(5), 21-34.

Schermer, M., Darnhofer, I., Daugstad, K., Gabillet, M., Lavorel, S., \& Steinbacher, M. (2016). Institutional impacts on the resilience of mountain grasslands: an analysis based on 
three European case studies. Land Use Policy, 52, 382-391. doi: https://doi.org/10.1016/j. landusepol.2015.12.009

Scott, R. (1995). Institutions and Organizations. Stanford, USA: SAGE.

Servicio de Información Agroalimentaria y Pesquera. (2018). Atlas Agroalimentario 2012-2018. México: Servicio de Información Agroalimentaria y Pesquera Retrieved from https://nube.siap.gob.mx/ gobmx_publicaciones siap/pag/2018/

Atlas-Agroalimentario-2018

Shapero, A. (1975). The displaced, uncomfortable entrepreneur. Psychology today, 9(6), 83-88.

Shapero, A., \& Sokol, L. (1982). The social dimensions of entrepreneurship. Encyclopedia of entrepreneurship, 72-90.

Sher, A., Adil, S. A., Mushtaq, K., Ali, A., \& Hussain, M. (2017). An investigation of entrepreneurial intentions of agricultural students. Pakistan Journal of Agricultural Sciences, 54(4), 941-945. doi: 10.21162/PAKJAS/17.5132

Slade Shantz, A., Kistruck, G., \& Zietsma, C. (2018). The opportunity not taken: The occupational identity of entrepreneurs in contexts of poverty. Journal of Business Venturing, 33(4), 416-437. doi: https://doi.org/10.1016/j.jbusvent.2018.02.003

Smelser, N. (2018). The sociology of economic life. New York, USA: Routledge.

Smelser, N. J., \& Swedberg, R. (2005). Introducing economic sociology. The handbook of economic sociology, 2, 3-25.

Thompson, E. R. (2009). Individual Entrepreneurial Intent: Construct Clarification and Development of an Internationally Reliable Metric. 33(3), 669-694. doi: 10.1111/j.1540-6520.2009.00321.x

Urban, B., \& Kujinga, L. (2017). The institutional environment and social entrepreneurship intentions. International Journal of Entrepreneurial Behavior \& Research, 23(4), 638-655. doi: 10.1108/IJEBR-07-2016-0218

Vargas, M. H. F., \& Restrepo, D. R. (2019). The instruments of public policy. A transdisciplinary look. Cuadernos de Administración, 35(63), 101-113.

Vasconcelos Pereira Leite, Y., Araújo de Morares, W. F., \& Santos Salazar, V. (2016). International entrepreneurship in agribusiness. Revista Galega de Economía, 25(1), 151-162.

Williamson, O. E. (1975). Las Instituciones económicas del capitalismo. Ciudad de México, México: Fondo de Cultura Económica.

Williamson, O. E. (1979). Transaction-Cost Economics: The Governance of Contractual Relations. The Journal of Law and Economics, 22(2), 233-261. doi: 10.1086/466942

Williamson, O. E. (1987). Transaction cost economics: The comparative contracting perspective. Journal of Economic Behavior \& Organization, 8(4), 617-625. doi: https://doi. org/10.1016/0167-2681(87)90038-2

Williamson, O. E. (1989). Transaction cost economics. In Handbook of Industrial Organization (pp. 135-182). Amsterdam, Nethearlands: Elsevier.

Yaseen, A., Saleem, M. A., Zahra, S., \& Israr, M. (2018). Precursory effects on entrepreneurial behaviour in the agri-food industry. Journal of Entrepreneurship in Emerging Economies, 10(1), 2-22. doi: 10.1108/JEEE-08-2016-0029

Yaseen, A., Somogyi, S., \& Bryceson, K. (2017). Entrepreneurial behaviour formation among farmers: evidence from the Pakistani dairy industry. Journal of Agribusiness in Developing and Emerging Economies, 8(1), 124-143. doi: 10.1108/JADEE-01-2017-0002 